Clarke and Kulkarni: Testing the Application of Heckscher-Ohlin Theorem

$\therefore$

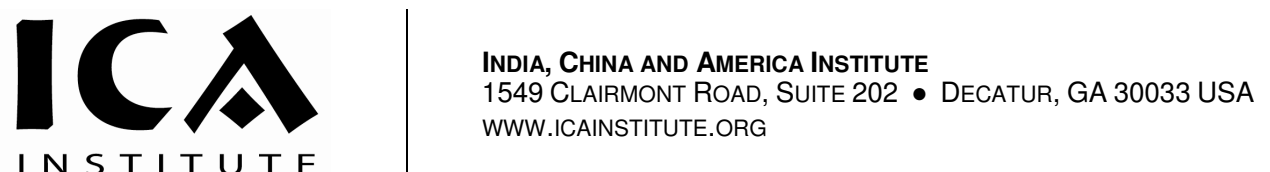

Testing the Application of Hecksehor-0hilin Theorem to Contemporary Trade Between Malaysia and Singapore

Andrew Clarke \& Kishore G. Kulkarni

Journal of Emerging Knowledge on Emerging Markets
Volume 1 Issue 1 


\title{
Testing the Application of Heckscher-Ohlin Theorem to Contemporary Trade Between Malaysia and Singapore
}

\author{
Andrew Clarke \\ Korbel School of International Studies, \\ University of Denver \\ Kishore G. Kulkarni \\ Professor of Economics and Editor, \\ Indian Journal of Economics and Business, \\ Metropolitan State College of Denver
}

Journal of Emerging Knowledge on Emerging Markets

Volume 1 Issue 1

November 2009

\section{Introduction}

ince members of the Association of Southeast Asian Nations (ASEAN) signed the ASEAN Free Trade Area agreement in 1992, trade between Singapore and Malaysia has continued to grow. Historically the economies of these two countries have had different characteristics, however, with Singapore known as a capital abundant country and a world financial center, while Malaysia has traditionally been relatively labor abundant and capital scarce. Because of this sharp contrast in their economies, one would expect that testing the Heckscher-Ohlin Theorem using trade data between Singapore and Malaysia would provide stark evidence of the H-O Theorem. That is to say that rather than find an 
exceptional case, as some past studies have done, this paper has attempted to find a country pair that seems to most closely resemble an idealized trade environment for the H-O Theorem. Thus, should a test find that the key hypotheses of the theory-namely that capital abundant countries export capital intensive goods, and labor abundant countries export labor intensive goods - are not evidenced in the data, then a serious re-evaluation of the theory may be necessary.

The paper will first review past tests of the Heckscher-Ohlin Theorem to determine what relevant studies have been done to date. Following that, export data will be reviewed for several different sectors, dividing them up as either capital intensive or labor intensive. What we would expect is that Singapore is exporting capital intensive goods to Malaysia, and Malaysia is exporting labor intensive goods to Singapore. Further, labor intensive exports will be analyzed as a proportion of capital intensive exports to determine how the labor/capital export ratio compares to the labor/capital abundance ratio for each country. Based on our findings, some conclusions will be able to made as to whether the HeckscherOhlin Theorem stands up to the test with respect to Malaysia and Singapore over time. We will also analyze theoretically what differences in export proportions imply about trade between the two countries.

\section{Theoretical Section}

\section{Heckscher-Ohlin: A Theoretical Explanation}

David Ricardo's highly influential theory of comparative advantage demonstrated how two countries could benefit from trade due to technological differences in production of the same goods. By 1912, however, two Swedish economists-Eli Heckscher and Bertil Ohlin-theorized that even if two countries had the same technology of production, trade could still be beneficial because they had different factor endowments. Thus, their landmark paper proposed, countries endowed with abundance of capital would export capital intensive goods and import labor intensive goods, whereas countries endowed with abundance of labor would export labor intensive goods and import capital intensive goods.

Factor endowment, also known as factor abundance, is defined in two ways as follows:

- Factor Ratio Definition:

- Suppose two Countries (A \& B) and two factors of production (capital=k \& labor=l);

- If $(\mathrm{k} / \mathrm{l}) \mathrm{A}>(\mathrm{k} / \mathrm{l}) \mathrm{B}$, then Country $\mathrm{A}$ is said to be capital abundant. By reversing the ratios, it follows that Country $\mathrm{B}$ is labor abundant: $(\mathrm{l} / \mathrm{k}) \mathrm{A}<(\mathrm{l} / \mathrm{k}) \mathrm{B}$ 
- Factor Price Definition:

- Suppose $\mathrm{k}$ and $\mathrm{l}$ have prices denoted as rental rate (r) and wage rate $(\mathrm{w})$

- If (w/r)A is the wage/rental ratio in Country A, and (w/r)B is the wage/rental ratio in Country B, then:

- When (w/r)A > (w/r)B, Country A is said to be capital abundant and Country B is said to be labor abundant.

Factor intensity refers to the amount of labor and capital required to produce a good, and is defined as follows:

- Suppose two goods ( $\mathrm{x} \& \mathrm{y})$ have two factors of production $(\mathrm{k} \& \mathrm{l})$;

- Suppose $(\mathrm{k} / \mathrm{l}) \mathrm{x}$ denotes the capital/labor ratio required to produce one unit of good $\mathrm{x}$, and $(\mathrm{k} / \mathrm{l}) \mathrm{y}$ denotes the capital/labor ratio required to produce one unit of good y;

- If $(\mathrm{k} / \mathrm{l}) \mathrm{x}>(\mathrm{k} / \mathrm{l}) \mathrm{y}$, then good $\mathrm{x}$ is said to be capital intensive and good $\mathrm{y}$ is said to be labor intensive.

In developing the theory, they created a set of six assumptions, which were:

1. The world is explained by a $2 \times 2 \times 2$ model, meaning there are two countries (A \& B), two goods ( $\mathrm{x} \& \mathrm{y}$ ), and two factors of production (capital=k \& labor=l).

2. Technology of production of the same good across countries is exactly the same. Therefore, one unit of good $\mathrm{x}$ requires the same amount of labor and capital in both countries. This also implies that if both countries had the same factor endowments, then their production combinations would be the same.

3. There is perfect competition in all production, meaning the price is equal to cost of production, and thus profit over time is zero.

4. Production occurs under increasing cost conditions:

a. This implies diminishing marginal productivity of resources (either labor or capital); 
b. After trade there is incomplete specialization in both countries;

c. Production possibility curves (PPCs) are concave to the origin.

5. Demand conditions in both countries are identical. This includes tastes of consumers, and expectations of future prices.

6. Both countries have free trade policies, without quotas, tariffs, or transportation costs.

Given these assumptions, the H-O Theorem says that if:

$(\mathrm{k} / \mathrm{l}) \mathrm{A}>(\mathrm{k} / \mathrm{l}) \mathrm{B}$ then Country A is capital abundant and Country B is labor abundant. And if:

$(\mathrm{k} / \mathrm{l}) \mathrm{x}>(\mathrm{k} / \mathrm{l}) \mathrm{y}$ then $\operatorname{good} \mathrm{x}$ is capital intensive and good $\mathrm{y}$ is labor intensive.

Thus, mutually beneficial trade will occur if Country A's resources specialize in production of good $\mathrm{x}$ and export good $\mathrm{x}$ to Country B, and if Country B's resources specialize in production of good y and export good y to Country A. The theory thus demonstrates that even if technology of production in two countries is the same, they can still engage in trade and have mutual benefits.

Because it was the first theory to go beyond Ricardo, demonstrating gains from trade without differences in technology, and integrating capital as a factor of production in addition to labor, the $\mathrm{H}-\mathrm{O}$ Theorem has been influential in reshaping the debate about gains from trade. Since its debut in 1912, however, many economists have tested the theory by analyzing real-world data, finding mixed results. The next section will examine past tests of the Heckscher-Ohlin Theorem.

\section{Literature Review}

In the introduction of his influential article, "The Case of the Missing Trade and Other Mysteries," Daniel Trefler writes about the Heckscher-Ohlin Theorem that, "empirically, the theory has been repeatedly rejected over the years and rightfully so: it performs horribly." (pg. 1029) He goes on to say that factor endowments correctly predict the direction of factor service trade about 50 percent of the time, "a success rate that is matched by a coin toss." (pg. 1029) Nevertheless, H-O continues to be tested because deviations from the theory have proven fruitful in expanding upon it, and thereby expanding upon our knowledge of the factors that drive trade. 
The first noteworthy test of the H-O Theorem was published in 1953 by Wassily Leontief, a Harvard professor who had analyzed 1947 data of U.S. trade in order to determine if the U.S., the most capital abundant country in the world at the time, was exporting capital intensive goods and importing labor intensive goods as the theory would presume. Using input/output tables of U.S. exports and import substitutes, Leontief examined 200 industries broken down into 50 sectors to analyze the factor intensity of each manufacture based on the factor intensity of its component parts. He found that exports in 1947 were 30\% more labor intensive than import substitutes, leading him to conclude that "America's participation in the international division of labor is based on its specialization on labor intensive, rather than capital intensive, lines of production." (pg. 343). Because it was contrary to the H-O Theorem, the finding became known as the Leontief Paradox.

Several theories as to why the H-O Theorem didn't hold up to Leontief's test were put forward in the years following. Leontief himself argued that because labor productivity in the U.S. was three times higher than the rest of the world, the U.S. was actually a labor abundant country. When other economists pointed out that capital was also more productive in the U.S., Leontief withdrew his argument. Others argued that the data may have been skewed in 1947 due to World War II having just ended, and Europe being unable to compete. Tests on later years showed that the Leontief Paradox diminished, but did not disappear.

Swedish economist Stefan Linder proposed what came to be known as Linder's Hypothesis (Linder, 1961), which noted the preeminence of consumer preference as a driver of international trade. The greater the similarity of tastes, Linder argued, the more likely it is that trade will emerge. Because U.S. consumers had a high preference for capital intensive goods in 1947, imports of capital intensive goods were necessary to meet demand. As a corollary, rest of world did not have high demand for such goods, capital intensive goods were largely consumed by the U.S. and not exported as much as labor intensive goods, which were in high demand in rest of world. This explanation of the Leontief Paradox was found to be insufficient, however, because it wasn't able to be tested quantitatively.

In fact it was not until a 1981 article by Robert Stern and Keith Maskus (Robert Stern, 1981) that the Leontief Paradox was finally put to rest. The article showed that when adding a third factor of production, namely natural resources, the Leontief Paradox disappears because many of the goods Leontief considered to be labor intensive were actually natural resource intensive.

In 1987 (Harry P. Bowen, 1987), a team of economists conducted what they humbly referred to as "the first systematic and complete evaluation of the relationships implied by the H-O-V Hypothesis among these three sets of variables." The three variables referred to are trade, factor endowments, and factor input requirements. The study 
analyzed 12 factors of production for 27 countries, and expanded the $\mathrm{H}-\mathrm{O}$ Theorem to allow for technological differences. The authors then calculated the ratio of each country's endowment of each factor to total world supply, and compared the ratios to each country's share of world income. The expectation under the H-O Theorem would be that a country would export those goods for which its factor share exceeded the income share. The study found that for two-thirds of the factors of production, trade occurred in the direction expected by the $\mathrm{H}-\mathrm{O}$ Theorem less than 70 percent of the time, leading the authors to conclude that the $\mathrm{H}-\mathrm{O}$ proposition that trade reveals factor abundance is "not supported by these data" (pg. 791).

Regarding this finding, Krugman points out that "this result confirms the Leontief paradox on a broader level: Trade often does not run in the direction that the HeckscherOhlin theory predicts." (Paul R. Krugman, 2000) Still, the authors note that although "the Heckscher Ohlin model does poorly, we do not have anything that does better. It is easy to find hypotheses that do as well or better in a statistical sense, but these alternatives yield economically unsatisfying parameter estimates." (pg. 805)

While the studies mentioned all seem to conclude that the Heckscher-Ohlin Theorem is an insufficient model of international trade, some two-country studies similar to the focus of this paper find support for $\mathrm{H}-\mathrm{O}$.

In a 1993 study (Richard A. Brecher, 1993), Richard A. Brecher and Ehsan U. Choudrhi analyzed bilateral trade data between the U.S. and Canada, using three variations of the $\mathrm{H}-\mathrm{O}$ model that each account for factor price differences in a unique way. They find that the most robust results come from the third model, which interpreted factor-price differences between industries as consequences of imperfect factor mobility. Thus the authors conclude that "the empirical evidence supports the $\mathrm{H}-\mathrm{O}$ production model after modifications to account for interindustry differences in factor prices." (pg. 283)

An earlier study (David Clifton, 1984) by two American economists tested the Heckscher-Ohlin Theorem using a different formulation for determining factor abundance than in other studies. Citing that past studies had inadequately measured abundance, the authors used the ratio of gross domestic product per worker versus gross world product per worker to compare the nine countries they examined with the rest of the world in order to determine factor abundance. After examining the GDP/laborer ratios for the United States, Ireland, Australia, New Zealand, the United Kingdom, Israel, Korea, Kenya, and Japan, the authors determined that Kenya and Korea were labor abundant, and the other countries were capital abundant. An analysis of each country's trade data showed that all but three exhibited trade flows congruent with $\mathrm{H}-\mathrm{O}$ theory. The United Kingdom, Israel, and Kenya were the countries that did not follow suit, however the authors were unable to discern a pattern that would give any indication as to why these countries failed to conform to the expected trade flow. 
Two other studies reviewed also seem more willing to give the Heckscher-Ohlin Theorem a chance. One is appropriately titled "Give Heckscher and Ohlin a Chance!" (Wood, 194) and like the Clifton study, criticizes past critiques of the H-O Theorem as inadequate because they have "mis-specified the theory by treating capital as similar to land." Wood concludes that because capital is internationally mobile, it doesn't actually influence the flow of trade, and finds that when capital is excluded, "[the H-O Theorem] often seems to perform rather well." Instead of labor/capital, Wood compared trade between pairs of developed and developing countries based on the skill of manufactures traded, finding that more sophisticated goods are exported by developed countries.

Krugman notes that these findings do not "contradict the observation that overall the Heckscher-Ohlin model does not seem to work very well, because North-South trade in manufactures accounts for only about 10 percent of total world trade."

And a 2003 paper by Peter K. Schott (Schott, 2003) takes into account factor intensity reversal when analyzing cross sectional trade data. Factor intensity reversal describes the way in which a single good can be considered capital intensive in a developed country because the mode of production is highly automated and computerized, whereas production of the same good in a developing country can be considered labor intensive because it is largely performed by human labor. After analyzing a range of industrial sectors and countries, Schott concludes that by analyzing countries' exports in terms of not only sector, but also the country-specific factor intensity of production, produces a richer set of findings. Ultimately, Schott's findings are in line with the H-O Theorem, though slightly modified, indicating that "countries specialize in subsets $^{l}$ of goods depending upon their relative factor endowments." (pg. 704)

Though results from the myriad tests of the Heckscher Ohlin Theorem vary, they tell us some important things about the theory. First, we see that despite all efforts to discredit it, the H-O Theory remains relevant, with papers and studies ongoing to determine whether Heckscher and Ohlin were wrong, or if we're just missing something. Second, this survey makes apparent the challenges in applying theory to real data. As many studies noted, measuring a country's factor abundance ratio remains a challenge because there remains no generally accepted approach to measuring "capital" for a country. Another difficulty that the studies demonstrate is in measuring factor intensity, since it is difficult to measure exactly labor and capital levels within a certain good, and harder still when one considers more factors of production, as some of the studies did. Some quarrel with H-O's basic assumptions, arguing that the model is too simplified because it assumes that there are no technological differences between countries. But even Trefler, whose criticisms were noted at the outset of this section, concluded in his

\footnotetext{
${ }^{1}$ Emphasis added
} 
1995 test of Heckscher-Ohlin that "the model that performed best combined Armington home bias with neutral international technology differences." (Trefler, 1995)

Though there seems to be an insistence on the part of some scholars to discredit the H-O Theorem, no doubt prompting the exclamation mark at the end of Wood's title, attempts at doing so have remained inconclusive. Leontief himself disagreed with his paradox, and in the end it was proven to be flawed because he was missing something: natural resources as a factor of production. Even the Bowen study confesses that though $\mathrm{H}-\mathrm{O}$ didn't stand up to scrutiny, their team was unable to come up with something better.

So, what is the relevance of the Heckscher-Ohlin Theorem?

Krugman concludes that, "the growth of North-South trade in manufactures-a trade in which the factor intensity of the North's imports is very different from that of its exports-has brought the factor proportions approach into the center of practical debates over international trade policy." (pg. 85)

It is hard to think of a more distinct North-South pair of countries that are more politically, economically, and geographically linked than Singapore and Malaysia. Singapore is the second largest destination for Malaysian exports, and fourth among sources for Malaysian imports. Malaysia, meanwhile, is the largest destination for Singaporean exports, and the largest among sources of Singaporean imports. Thus, the following section will conduct a test of the Heckscher-Ohlin Theorem on trade between these two countries in order to determine whether their trade patterns conform to the model, or if not, determine the cause of the divergence.

\section{Empirical Section}

\section{Overview of Malaysia/Singapore Economies}

\section{Malaysia 2007}

Like many other developing Asian nations, Malaysia has pursued a policy of state-led development for at least three decades. Though the state has been highly interventionist in markets, it has maintained a bias toward promoting growth in the private sector, particularly since the 1991 Privatization Master Plan, which made the private sector the major engine of economic growth. This domestic initiative coincided with the January 1992 signing of the ASEAN Free Trade Area, which was entered into by six of the ASEAN members, including Malaysia and Singapore. By 2007, Malaysia had complied almost fully with the tariff goals of the AFTA, bringing import tariffs on signatory nations' goods down to 0-5\% for 97\% of all goods, (Economist Intelligence Unit, 2008) with some notable exceptions like vehicles and rice. This broad reduction of import 
tariffs from ASEAN partners has led to a growth in regional imports as a proportion of rest of world imports, going from 10\% in 1991 to 22\% in 2001. (Madani, 2001)

This economic growth strategy has paid dividends, as the Malaysian economy continued its strong growth trajectory in 2007, with $6.3 \%$ GDP growth, driven in large part by an increase in private domestic consumption of $11.7 \%$, and a $12.3 \%$ increase in private expansion, particularly in the oil and gas, manufacturing, services, and construction sectors. This growth pattern has been steady since the ASEAN Free Trade Agreement of $1992\left(\right.$ see graph $\left.^{2}\right)$. Part of the strength in Malaysia's economy has been its ability to export manufactured goods, particularly laborintensive electronics, as well as agricultural products such as rubber, palm oil, cocoa, and

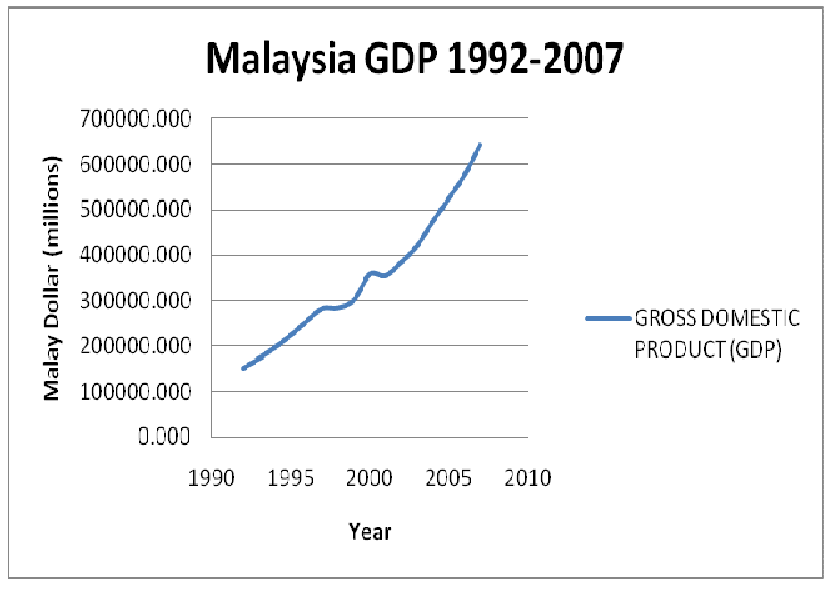
minerals and oil (Economist Intelligence Unit, 2008). Still, manufactured goods stood out, with $70.9 \%$ of total exports, followed by minerals and oil at $15 \%$ of total exports, and agricultural products with $11 \%$ of total exports. (WTO, 2009)

As it continues to develop, however, Malaysia has made diversification of its economy a priority. In the Ninth Malaysia Plan from the central government, announced in 2006, there were five "thrusts" cited as priorities for the future of Malaysia economic growth:

1. Move the economy up the value chain;

2. Enhancing education and training;

3. Reducing poverty and economic inequalities;

4. Improving quality of life;

5. And strengthening institutions.

This demonstrates Malaysia's commitment to shifting into more value-added, knowledge-based production. Further evidence of this commitment came in March of 2007, when plans for the Iskander Development Region (IDR) were announced. The IDR is Malaysia's answer to high-end business in Singapore. Bordering Singapore, the IDR offers special incentives for six sectors: creative industries, education services, financial advisory and consulting services, health care services, logistics services, and tourism activities.

2 Data source: International Monetary Fund, International Financial Statistics Database 
Still, as of 2007 Malaysia remained a relatively labor abundant country when compared with Singapore. Consider that Malaysia's GDP in 2007 was approximately 123 billion (in terms of the IMF special drawing rights, which represent a basket of U.S. dollars, euros, pounds, and yen), while their labor force was 10.4 million. If we consider "capital" of a country to be five times GDP, then Malaysia's capital to labor ratio in 2007 was 59. Singapore, however, had a slightly smaller GDP in 2007, coming in at 113 billion (SDR), yet its labor force was just 1.9 million. Thus, using a multiplier of five for the nation's capital again, Singapore has a capital to labor ratio of 297.

In the next section we will explore how Singapore became so capital abundant.

\section{Singapore: 2007}

The first thing to understand about Singapore is that it is a city-state, one of the few remaining in the world. It is also heavily urbanized throughout much of the territory, making for a scarcity of natural resources and land. Thus, Singapore has been forced to maximize a strategy of value-added manufacturing in order to be competitive. Economic reform began in earnest in 1968, when Singapore began to import raw materials and export finished goods. This strategy was aided by the fact that Singapore has a geographically favorable

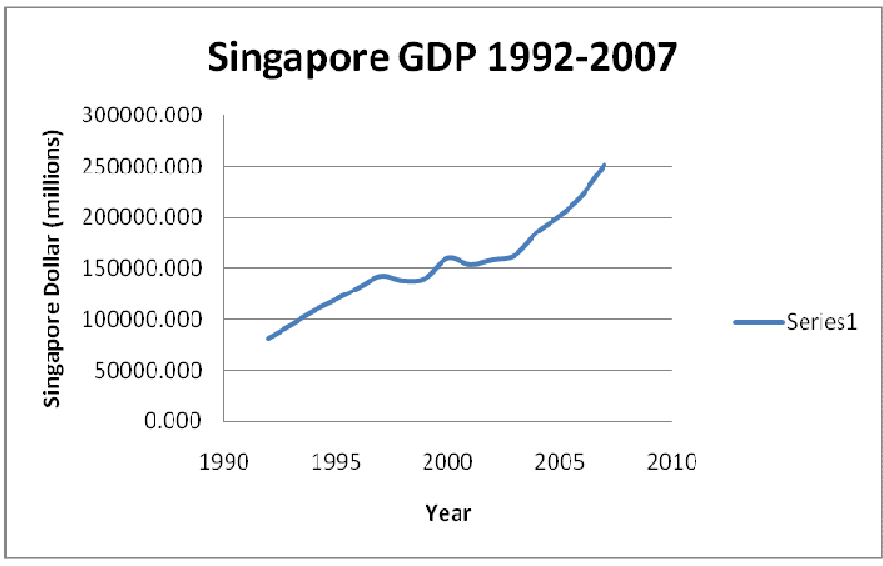
location, with a large port situated in a major shipping route. That location, coupled with favorable tax policies for foreign investors and heavy government investment in infrastructure and education, helped Singapore to develop. Consider Singapore's role in the oil trade. Though it has little of its own domestically produced oil, Singapore was able to attract some of the majors like Royal Dutch Shell and Esso to set up refineries, becoming the third largest refining center in the world by the 1970s, (Loeper, 1989) and remains a major refining hub, with the ExxonMobil refinery there the fifth largest in the world. This strategy has helped Singapore become one of the wealthiest countries in the world, with a GDP per capita (PPP) ratio of $\$ 51,142$ in 2008 , far greater than Malaysia's \$14,071 in the same year.

Singapore's economy is heavily trade dependent, with a trade to GDP ratio of $447^{3}$ for 2005-2007, and trade per capita of \$140,848 (USD). Though Malaysia is also trade

${ }^{3}$ WTO Data 
dependent, it is relatively much less so, with a trade to GDP ratio of 209 , and a trade per capita of $\$ 12,683$ (USD) for the same period. Singapore has also become more regiondependent since the signing of the AFTA, with its regional-to-world export ratio rising from $10 \%$ in 1991 to $35 \%$ in 2001, far surpassing even Malaysia's heavy regional dependency.

Yet as Malaysia seeks to move its way up the economic food chain from agriculture, labor intensive manufacturing, and extraction to more value-added production as discussed in the previous section, Singapore too is working to move up the ladder from value-added manufacturing and efficient, capital-intensive production to a more innovation driven economy. "Traditionally, Singapore has billed itself as an efficient business city," says a World Bank report. (Song-Tan, 2005) "The ability to provide quality infrastructure services more efficiently than neighboring countries has long given the city-state a comparative advantage in the manufacturing sector."

Still, as we shall see, in its commodities exports to Malaysia, while Singapore has a unique mix of exports, it nevertheless remains strongest in traditional products like electronics, refined petroleum, and machinery.

\section{Testing the H-O Theorem}

\section{Test Methodology}

What this paper will attempt to do in the next section is to find out the nature of the exports from Malaysia to Singapore and Singapore to Malaysia to determine whether they are as one would expect based on the Heckscher-Ohlin Theorem, or not. Based on the above description of the two economies, the H-O Theorem says that Malaysia as the relatively labor abundant country should export labor intensive goods to Singapore, and conversely, Singapore as the relatively capital abundant country should export capital intensive goods to Malaysia. Due to a scarcity of data, on bilateral trade by sector, the data to be examined will be from United Nations Comtrade, a database of commodities traded between countries. Because the sectoral breakdown in this database isn't particularly refined, we will use the data in conjunction with other information about the nature of the sectors in each country in order to determine whether the goods being exported are, on the whole, capital intensive or labor intensive. Take for example the category of "mineral fuels," which ranks number two on the commodities exports list for both countries. Though a major export for both countries, Malaysia, as the 25th largest petroleum producer in the world with 750,000 barrels per day of production ${ }^{4}$, exports primarily crude oil to Singapore for refining, which Singapore then exports back to Malaysia as gasoline or heating oil. Therefore, Malaysia's export of mineral fuels is largely labor intensive, whereas Singapore's export of mineral fuel is largely

${ }^{4}$ Source: CIA World Factbook 
capital intensive. This type of analysis will be done when comparing exports between the two countries in order to avoid mischaracterizing the nature of their exports.

Applying the Test
\begin{tabular}{|lr|}
\hline \multicolumn{2}{|c|}{ Singapore to Malaysia Trade } \\
\hline \multicolumn{2}{|c|}{2007} \\
Good & Amount \\
\hline Electrical Machinery & 16,920 \\
\hline Mineral Fuels & 6392 \\
\hline Machinery & 5825 \\
\hline Plastic/plastic products & 1433 \\
\hline Organic chemicals & 808 \\
\hline Optical/photographic & 639 \\
\hline iron/steel & 588 \\
\hline copper & 361 \\
\hline pearls/precious stones & 349 \\
\hline vehicles & 296 \\
\hline Chemical products & 264 \\
\hline Aluminum & 255 \\
\hline Clocks & 232 \\
\hline Paper & 230 \\
\hline Cutlery & 175 \\
\hline Perfumes/cosmetics & 174 \\
\hline Dyeing extracts & 165 \\
\hline Beverages & 150 \\
\hline Inorganic chemicals & 128 \\
\hline Rubber & 118 \\
\hline
\end{tabular}

\begin{tabular}{|l|r|}
\hline \multicolumn{2}{|c|}{ Malaysia to Singapore Trade } \\
\hline \multicolumn{2}{|c|}{ 2007 } \\
Good & Amount \\
\hline Electrical machinery & 9450 \\
\hline Mineral Fuels & 7040 \\
\hline Machinery & 4170 \\
\hline Iron/steel & 737 \\
\hline Plastics/plastic products & 720 \\
\hline Fats and oils & 564 \\
\hline Aluminum & 536 \\
\hline Optical/photographic & 441 \\
\hline Pearls/precious stones & 283 \\
\hline Aircraft/spacecraft \& & \\
parts & 258 \\
\hline Organic chemicals & 249 \\
\hline Copper & 228 \\
\hline Paper & 220 \\
\hline Chemicals & 218 \\
\hline Furniture & 200 \\
\hline Live animals & 169 \\
\hline Clocks & 168 \\
\hline Dairy & 152 \\
\hline Wood & 151 \\
\hline Salt & 150 \\
\hline & \\
\hline
\end{tabular}

In looking at the data, we can make some qualitative observations with regard to factor intensity of the exported goods. Electrical machinery is first on both lists of exports, and based on the readings we know that electronics production in Singapore is more efficient, using fewer units of labor for a unit of output, making it possible for the much less labor endowed Singapore to export nearly double the electronics to Malaysia than Malaysia exports to it. This high exchange of electronics does lend some credence to

${ }^{5}$ Amounts for both tables are in millions of US Dollars. 
Krugman's intra-industry argument. However, because of the relative factor proportions of production in each country, with electronics production much more labor intensive in Malaysia than Singapore, we see that factor intensity reversal has occurred, and that in fact both countries are exporting as one would expect based on the Heckscher-Ohlin Theorem.

We can also analyze the relative factor intensities quantitatively, however due to a lack of relevant data, we will have to assume that electronics manufacturing makes up the same proportion of the whole manufacturing sector in both countries. If we make that assumption, which is not a great stretch given that both countries have a high volume of electronics production, we can then consider the proportion of exports to total manufacturing labor in each country (for which data is available). In Malaysia in 2007, there were 1.977 million people working in the manufacturing sector, whereas in Singapore in the same year, there were 103,000 people working in manufacturing. Recall, factor intensity is defined as $(\mathrm{k} / \mathrm{l}) \mathrm{x}$, then the factor intensity ratio for manufacturing in Malaysia in 2007 was $\$ 4,780$ per laborer, and in Singapore was $\$ 16,427$ per laborer ${ }^{6}$. Thus, while the factor intensity of manufactured exports from Singapore to Malaysia was approximately 3.5 times as capital intensive, and thus demonstrates the $\mathrm{H}-\mathrm{O}$ conclusion to hold up, we would expect the factor intensity of Singaporean exports to be five times as capital intensive based on the relative factor abundance (recall, Singapore's capital/labor ratio was 297, while Malaysia's was 59).

Another sector for which labor statistics were able to be obtained is categorized as "mining, fishing, and agriculture." In looking at the export tables, we can consider several of the commodities as part of this category, including: iron/steel, copper, aluminum, fats and oils, live animals, salt, and dairy. In this sector, Malaysian exports to Singapore accounted for roughly $\$ 2.5$ billion with 1.6 million laborers, or a capital to labor ratio of $\$ 1,585$ of output per laborer. Meanwhile, Singaporean exports to Malaysia accounted for roughly $\$ 1.2$ billion with 313,000 laborers, or a capital to labor ratio of $\$ 3,846$ of output per laborer. Again, we see in mining, fishing and agricultural exports that though intra-industry trade is occurring, the factor intensity of Singaporean exports is relatively capital intensive, while Malaysian exports are relatively labor intensive.

The remaining labor categories with available data unfortunately don't include industry sectors that would involve exported goods, such as real estate or construction, or are found in the commodity trade tables, like financial services. Still, we can look at some of the remaining commodity exports from the tables to identify some general qualitative patterns. The Singaporean exports include a much higher ratio of finished goods, high-

${ }^{6}$ Note: Labor statistics obtained from the International Labor Organization labor statistics database. 
tech goods, and/or luxury items. These goods include plastic products, optical and photographic equipment, organic chemicals, vehicles, jewelry, perfumes, etc. Together these type of goods, which can be considered capital intensive in terms of their production, account for $\$ 4.8$ billion of exports to Malaysia, or $13.5 \%$ of total exported commodities (among the top 20 export sectors). Malaysian exports, however, include some of these same capital intensive product categories, however as a smaller proportion to the whole. Consider, capital intensive Malaysian commodity exports to

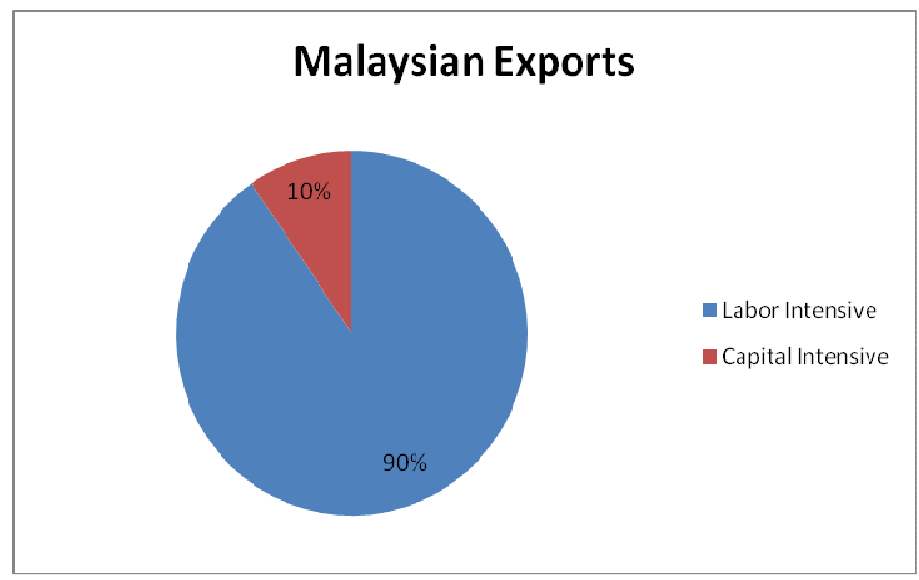
Singapore $^{7}$ totaled $\$ 2.3$ billion, or $8.9 \%$ of the total export mix.

Considered another way, if the commodity groups are divided into two categories: labor intensive and capital intensive, we can compare the ratio of exports in each category

\section{Singaporean Exports}

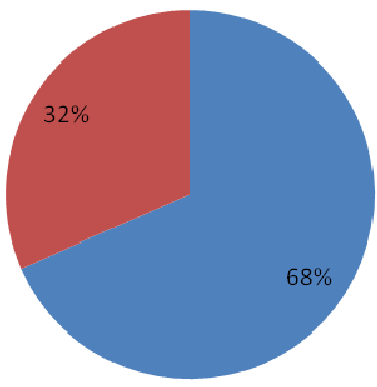

from each country. Malaysian exports were found to be almost exclusively labor intensive, or $90 \%$ of the total (see graph). Singaporean exports, meanwhile, were much more capital intensive. It is important to note that although Singapore's exports were majority labor intensive in this finding, recall that the data used is

only for commodities' exports, so one would imagine that much of that production would involve labor. Still, Singapore's commodities exports were $32 \%$ capital intensive and just $68 \%$ labor intensive ${ }^{8}$.

\footnotetext{
${ }^{7}$ Considered as: plastic products, spacecraft, pearls, chemical products, organic chemicals, clocks, optical/photographic

${ }^{8}$ Note that, as outlined in the previous section, mineral fuels can be considered capital intensive production in Singapore and labor intensive production in Malaysia. The other export categories considered to be capital intensive for Singapore were: plastic products, organic chemicals, optical/photographic, jewelry, vehicles, chemical products, clocks, cutlery, perfume, dyeing
} 


\section{Conclusion}

Though any conclusions reached from these tests must be tempered by an understanding of the inherent flaws of the data, and the assumptions that had to go into the methodology for reaching determinations, some observations can be made from the quantitative and qualitative findings in the previous section.

First, we find that in a relative sense, Singapore can be considered capital abundant and Malaysia can be considered labor abundant. We also find that the two countries are closely linked economically, politically, and geographically, giving them high relative proportions of bilateral trade, and thus making them a worthwhile country pair to compare when testing the Heckscher-Ohlin Theorem. When comparing the relative factor intensities of sectors for which data was available, a questionable yet not entirely unreasonable method of comparing the export category with the corresponding labor category, and finding the capital output for each unit of labor employed. When applying this method to the two available sectors-manufacturing and agriculture/miningSingapore's exports were found to be relatively capital intensive and Malaysia's exports were found to be relatively labor intensive. This meets the hypothesis of the H-O Theory. However, when looking at the factor intensity ratios of these two sectors in comparison with the factor abundance ratio, we found that Singapore's exports were relatively lower in terms of capital intensity than would be expected by H-O. Recall, Singapore's capital/labor abundance ratio was found to be 297, while Malaysia's was 59. Therefore Singapore can be considered approximately five times more capital abundant. However, for manufactured goods exports, Singapore's exports were only 3.5 times as capital abundant as Malaysia's, and for agriculture/mining exports, Singapore's were only 2.5 times as capital abundant. Therefore, this finding suggests that Malaysia is exporting more than their expected share of capital intensive goods to Singapore.

Likewise, the other assessment conducted on the export data, dividing it up between labor and capital intensive sectors, found that $90 \%$ of Malaysian commodity exports were labor intensive, while $68 \%$ of Singaporean commodity exports were labor intensive. With the caveat of this data only considering commodities trade, and not other critical sectors like financial services, or other professional services, which Singapore is known to be a world leader in, we can see just from the commodity data that Singapore exports are significantly more biased toward capital intensive production, even in commodities.

Thus we can conclude that with respect to Singapore/Malaysia trade in 2007, the general thesis of the Heckscher-Ohlin Theorem is found to be accurate, with capital

extracts, beverages, and inorganic chemicals. The export categories considered to be capital intensive for Malaysia were: plastic products, optical/photographic, precious stones, aircraft/spacecraft parts, organic chemicals, chemicals, furniture, and clocks. 
abundant Singapore exporting capital intensive goods to Malaysia, and labor abundant Malaysia exporting labor intensive goods to Singapore, though the factor intensity of the exports were not consistent with the factor abundance of the countries.

\section{References}

David Clifton, W. M. (1984). An Empirical Investigation of the Heckscher Ohlin Theorem. The Canadian Journal of Economics , 32-38.

Economist Intelligence Unit. (2008). Country Commerce: Malaysia. New York: Economist Intelligence Unit.

Harry P. Bowen, E. E. (1987). Multicountry, Multifactor Tests of the Factor Abundance Theory. The American Economic Review , 791-801.

Linder, S. (1961). An Essay on Trade and Transformation. New York: John Wiley.

Loeper, B. (1989). U.S. Library of Congress Country Studies. Retrieved May 14, 2009, from U.S. Library of Congress: http://countrystudies.us/singapore/11.htm

Madani, D. (2001). Regional Integration and Industrial Growth Among Developing Countries: The Case of Three ASEAN Members. New York: World Bank.

Paul R. Krugman, M. O. (2000). International Economics. New York: Addison Wesley.

Richard A. Brecher, E. U. (1993). Some Empirical Support for the Heckscher-Ohlin Model of Production. The Canadian Journal of Economics , 272-285.

Robert Stern, K. M. (1981). Determinants of the Structure of U.S. Foreign Trade. Journal of International Economics, 207-224.

Schott, P. K. (2003). One Size Fits All? Heckscher-Ohlin Specialization in Global Production. American Economic Review , 686-708.

Song-Tan, K. (2005). From Efficiency Driven to Innovation Driven Economic Growth: Perspectives from Singapore. Singapore: World Bank.

Trefler, D. (1995). The Case of the Missing Trade and Other Mysteries. American Economic Review, 1029-1046.

Wood, A. (194). Give Heckscher and Ohlin a Chance. Weltwirtschaftliches Archiv, 20-49.

WTO. (2009, May 7). World Trade Organization Statistics Database. Retrieved May 14, 2009, from World Trade Organization: http://www.wto.org/english/res_e/statis_e/statis_e.htm 